\title{
DETERMINING THE MEANING OF AN INNUENDO: CAN THE CONTEXT BE SEPARATED FROM THE WORDS?
}

Introduction

Defamation can be said to mean the wrongful and intentional publication of defamatory material which refers to a plaintiff (Loubser, Midgley, Mukheibir, Niesing and Perumal The Law of Delict in South Africa (2010) 329). In order for liability to arise in a defamation action there must be publication of defamatory material which refers to the plaintiff, and the plaintiff bears the onus of proving this (Loubser et al 329; for a full discussion of the elements see Loubser et al 332-345; Neethling, Potgieter and Visser Neethling's Law of Personality 2ed (2005) 131-166; Burns Communications Law 2ed (2009) 202-228; and Foodworld Stores Distribution Centre (Pty) Ltd v Allie [2002] 3 All SA 200 (C)). From the plaintiff's perspective, the publication requirement entails a factual enquiry, whilst the determination of whether the publication was defamatory is more complex (for a full discussion of the elements see Loubser et al 332-345; Neethling et al 131-166; and Burns 202-228).

To determine whether a publication is defamatory one has to, firstly, establish the meaning of the publication, and secondly, decide whether the meaning of the publication contained a defamatory imputation (Sindani $v$ Van der Merwe 20022 SA 32 (SCA) par 10). However, this enquiry to establish the meaning of the material in question can become complicated considering that words may have more than one meaning and plaintiffs are entitled to rely on the secondary meaning of the words (also known as innuendos) in defamation actions.

Recently the Supreme Court of Appeal ("SCA") was called upon to decide the correctness of a High Court's approach in determining the meaning of an innuendo (Molotlegi v Mokwalase [2010] 4 All SA 258 (SCA)). In the High Court a separation of issues order was granted with the effect that the meaning of the innuendo in question had to be established without any regard to the context in which the words were uttered. This note will therefore consider whether a separation of issues, that is, separating the determination of the meaning of the words from the context in which they were uttered, would be appropriate in defamation cases where the secondary meaning of the words is relied upon by the plaintiff. In what follows, we shall consider what an innuendo is, the court's approach to determining the meaning of innuendos, the legal principles underlying a separation of issues order, and the decision of the Supreme Court of Appeal in Molotlegi v Mokwalase (supra). 


\section{The meaning of words}

Words can either convey a primary or a secondary meaning. The primary meaning of words refers to the normal meaning which is given to them by the reasonable person (Sindani $v$ Van der Merwe supra par 11). A plaintiff may, however, allege that the publication has a secondary meaning, a socalled innuendo. Secondary meanings, or innuendos, convey meanings that are uncommon from their primary meaning. "In certain instances a secondary meaning, or an innuendo, can convert an otherwise innocuous statement into a defamatory one" (Roberts $v$ Johncom Media Investments Ltd [2007] JOL 19012 (C) par 9). Innuendos usually arise where special circumstances precede the published words, which special circumstances are known to both the plaintiff and defendant, or are unusual meanings which can be attributed to the material by a person who has knowledge of the special circumstances (National Union of Distributive Workers $v$ Cleghorn \& Harris Ltd 1946 AD 984 992; Argus Printing \& Publishing Co Ltd $v$ Esselen's Estate 19942 SA 1 (A) 21; and W v Atoll Media (Pty) Ltd [2010] 4 All SA 548 (WCC) par 31).

\section{Courts approach to determining the meaning of innuendos}

In 1916 the Appellate Division had the task of deciding whether words, which were otherwise perfectly innocent on the face of it, could in fact be regarded as being defamatory by reason of the special circumstances which existed at the time and the place where they were published ( $G$ A Fichardt Ltd $v$ The Friend Newspapers Ltd 1916 AD 1 9; and also referred to in Mohamed $v$ Jassiem 19961 SA 673 (A) 707). At the time of this case counsel for the appellants were unable to refer the court to any previous decisions in support of such contention ( $G$ A Fichardt Ltd $v$ The Friend Newspapers Ltd supra 9). Our courts have come a long way since 1916 with the result that innuendos can today, without a doubt, be relied upon in defamation suits.

Today, a secondary meaning or innuendo can be relied upon by a plaintiff in those instances where there are special circumstances, which special circumstances are known to the communicator and the communicatee (Loubser et al 335; Neethling and Potgieter Neethling-Potgieter-Visser Law of Delict 6ed (2010) 334; and Sutter v Brown 1926 AD 155 162). Apart from alleging the secondary meaning and the circumstances warranting the defamatory inference in the pleadings, the courts require a plaintiff to prove the existence of the special circumstances by leading evidence (Yates $v$ Macrae 1929 TPD 480 487; Koening v Fox 1944 CPD 133 135; Kidson v SA Associated Newspapers Ltd 19573 SA 461 (W) 467; and Deedat v Muslim Digest 19802 SA 922 (D) 930). A secondary meaning cannot be relied upon where it has not been alleged in the plea (or amended plea). "Proof becomes necessary of the special circumstances within the knowledge of the defaming party which would give to words innocent in themselves a defamatory significance appreciated by the hearers. So that the evidence of the latter becomes ... material and necessary" (Sutter v Brown supra 164). 
The plaintiff is therefore required to prove, on a balance of probabilities, that there were persons who were aware of the special circumstances who received the published material, and who were likely to have interpreted the publication in the defamatory way (Hassen $v$ Post Newspapers (Pty) Ltd 19653 SA 562 (W) 566).

It is apparent that the meaning of an innuendo is determined with reference to the special circumstances or context in which it was made. Therefore, legal precedent in defamation cases dictates that it is not possible to determine the meaning of the innuendo independently of the context or special circumstances alleged. However, the legal principles underlying a separation of issues order need to be consulted to determine whether such a separation is perhaps possible on procedural grounds.

\section{$4 \quad$ Separation of issues}

In any action pending before a court, the court may make an order that a question of law or fact may be decided either before any evidence is led or separately from any other question, i.e. that is separately from the rest of the case, if it appears to the court that such question of law or fact may conveniently be decided upon either before any evidence is led or separately from any other question (Rule 33(4) of the Uniform Rules of Court; and Pete, Hulme, Du Plessis and Palmer Civil Procedure: A Practical Guide (2008) 465). A court may make such an order either of its own accord, or upon application by any party (Rule 33(4) of the Uniform Rules of Court; and Pete et al 465). However, where application is made by a party to the litigation the court is obliged, by Rule 33(4), to grant the application and allow the question of law or fact to be decided separately, unless it appears to the court that the question cannot be decided separately conveniently (Rule 33(4) of the Uniform Rules of Court; and Pete et al 465).

The purpose of this Rule is to facilitate the convenient and expeditious dismissal of the claim (Denel (Edms) Bpk v Vorster 20044 SA 481 (SCA) 485A-B; and Theophilopoulos, Rowan, Van Heerden and Boraine Fundamental Principles of Civil Procedure (2006) 304). "It provides a mechanism to test an alleged lacuna in the plaintiff's case or to determine a factual issue which can give direction to the rest of the case and, in particular, to obviate the leading of evidence in order to determine the plaintiff's claim without the cost and delays of a full trial" (Theophilopoulos et al 304; and Van Loggerenberg, Dicker and Malan "Separation of Issues in Terms of R 33(4)" August 2005 De Rebus 30). In determining whether a separation of issues should be ordered, the court should not only consider expedience, but also notions of appropriateness and fairness (Theophilopoulos et al 304; and Van Loggerenberg et al August 2005 De Rebus 30). Courts have warned that a separation of issues which has not been properly considered and carefully circumscribed will come back to haunt the parties (Denel (Edms) Bpk $v$ Vorster supra 485A-E; and Theophilopoulos et al 30). 
Therefore, courts should carefully consider whether the issues to be separated can be determined independently of each other before granting such an order. On notions of appropriateness, fairness and expeditiousness it should be clear that one cannot determine the meaning of an innuendo in a defamation case without reference to the context in which it was published since it is not appropriate to separate the context from the words. It would be unfair to expect the plaintiff to prove the defamatory effect of the words without evidence of the context where the defamatory imputations lie in the context of the words. Despite this apparent clarity, it appears our courts still get this wrong and allow the determination of the secondary meaning of words to be decided without reference to the circumstances in which they were uttered (Molotlegi $v$ Mokwalase supra). Fortunately, in this case the SCA was called upon to resolve the confusion.

\section{$5 \quad$ Molotlegi v Mokwalase}

\section{Facts}

On 13 October 2006, in a protocol and security meeting of the Royal Bafokeng Nation, the first appellant uttered the following words to the respondent in the presence of other members: "Mokwalase, you are fired. I don't want to see you again on my premises. You can excuse yourself." Accordingly the respondent issued summons against the first appellant and the Royal Bafokeng Administration, the legal persona responsible for the administration of the Royal Bafokeng Nation (the second respondent). Based on the special circumstances surrounding the words uttered, the respondent alleged that the words were intended to mean, and were understood by him and the members at the meeting to mean, that he was "unable to perform his duties in a professional manner", he "was deemed an undesired person on the premises of the Royal Bafokeng Nation", and that he was "not even worthy of proper disciplinary action and/or the rules of natural justice" (par 14). The respondent alleged that the first appellant's conduct and the words uttered in the meeting were defamatory and wrongful given the context of the meeting, the position the first respondent held in the Royal Bafokeng Nation, a team leader of the protection team, and the manner in which the words were uttered.

\section{Court a quo}

The issue to be decided by the court a quo, which was the North West High Court in Mafikeng, was whether the words uttered by the first appellant were wrongful and defamatory given the context in which they were published (par 3 ). However, before the hearing of the matter the appellants applied to the court for a separation of the issues in terms of Rule 33(4) of the Uniform Rules. The appellants applied for, amongst others, the meaning of the alleged defamatory words to be determined separately from the context of the meeting in which they were uttered (par 4). The application was granted (per Matlapeng AJ). 
Thereafter the court a quo found in favour of the respondent holding that the words uttered were defamatory in nature, without the respondent having led any evidence about the context in which the words were uttered (per Mogoeng JP) (par 6). The court went on to find that the publication of these defamatory words was also wrongful and was done with the requisite animus iniuriandi. Thus, the court found that the respondent had proved the case of defamation (par 6).

\section{Supreme Court of Appeal}

Initially the appellants based their appeal on three grounds: (i) that the court a quo erred in its finding that the words uttered were wrongful and made with animunis iniuriandi since the only issue before the lower court, in terms of the separation order, was whether the words uttered by the first respondent were defamatory; (ii) that the court a quo erred in finding that the words were defamatory without considering the special circumstances or context in which they were uttered; and (iii) that the court erred in its finding that the words uttered were defamatory in the sense pleaded (par 7). However, at the hearing of the appeal the appellants confined their submission to one ground - that the court a quo erred in its finding that the words uttered were defamatory without having heard evidence of the special circumstances which surrounded the utterances (par 8).

Writing for the majority, Bosielo JA remarked that the respondent clearly relied on the secondary meaning of the words in his particulars of claim and not the primary meaning of the words. The court noted that the application for the separation of issues "unduly limited the issue" to the words merely uttered without having regard to the special circumstances as pleaded by the respondent and the innuedo which the respondent attributed to the words (par 15). Bosielo JA held that since the respondent relied on an innuendo it was not possible to determine the meaning of the words without any evidence being led as to the existence of special circumstances (par 15). The meaning of an innuendo cannot be limited to the words uttered without hearing evidence on the special circumstances. The court found that separating the special circumstances from the determination of the defamatory effect of the words, where the plaintiff relied on an innuendo, was erroneous (par 15-16).

Given that the respondent had not been afforded an opportunity to lead evidence regarding the special circumstances and context of the words, in order for the court to decide on the proper meaning to be attributed to them in innuendo, the court set aside the decision of the court a quo (par 16 and 21) (the court also found that the court a quo had gone beyond what it was required to do in terms of the separation order; and par 17). The appeal was upheld. 


\section{$6 \quad$ Conclusion}

One would have assumed that it is trite that a plaintiff relying on an innuendo in a defamation case has to prove the existence of special circumstance in order for the court to make a final decision on the defamatory nature of the material. However, these principles of law appear to have escaped the knowledge of the legal team acting on behalf of the appellants in Molotlegi $v$ Mokwalase (supra), as well as that of the judge who heard the separation of issues application, and the judge of first instance who made the defamatory finding. Thankfully, the SCA set matters straight on this point (but not without the parties having to incur further fees and delays in taking the matter on appeal).

Litigants are required to bear in mind that a separation of issues application will not be appropriate and expeditious in all matters. Such orders should only be sought by litigating parties where it is clear that the issues may be decided independently. From this note we hope that one shall realize that it will not be possible to determine the meaning of words separately from the context in which they were published in defamation cases where an innuendo is relied upon. Hopefully this decision may help to prevent this result from occurring again in our courts, and possibly end up saving future litigants the expense of and delay in having to take the matter on appeal in order to get the correct result.

Christin Gowar and CJ Visser University of the Witwatersrand, Johannesburg 